\title{
Fermentação de glicose por Zymomonas mobilis CP4 utilizando a técnica de cultivo contínuo operado de forma transitória
}

\author{
Fermentation of glucose by Zymomonas mobilis CP4 utilising \\ continuous transient technique
}

\author{
João Batista Buzato ${ }^{1}$; Maria Antonia P.C. Celligoi ${ }^{2}$
}

Resumo

\begin{abstract}
Foi estudado a conversão de glicose em etanol por Zymomonas mobilis CP4 utilizando a técnica de cultivo contínuo operado de forma transitória.. A bactéria cresceu em meio de glicose com concentrações alternadas de 2 e $5 \%(\mathrm{P} / \mathrm{V})$ submetida em ciclos de tempos de 2, 4 e 6 horas. A produção de etanol foi comparada com fermentação contínua simples utilizando glicose a 3,5\%(P/V). O valor para taxa de diluição foi fixado em $0,2 \mathrm{~h}^{-1}$ para ambas técnicas de fermentação. Quando foi testado o ciclo de tempo de 2 horas, os valores de biomassa e etanol mantiveram-se constantes. A aplicação do ciclo de tempo de 4horas produziu respostas pouco pronunciadas pela bactéria. Os valores de biomassa oscilaram de 0,7 a $0,93 \mathrm{~g} / \mathrm{L}$. Quando o ciclo de tempo de 6 horas foi aplicado, as oscilações nos valores de biomassa e etanol foram bem pronunciadas. Os valores mínimo e máximo de biomassa foram respectivamente 0,61 e $1 \mathrm{~g} / \mathrm{l}$. A eficiência de conversão em etanol foram de 84, 85 e $89 \%$ (correspondente respectivamente ao ciclo de tempo de 2, 4 e 6 horas enquanto que o cultivo contínuo simples a eficiência de conversão foi de 50\% do teórico.

Palavras chave: Zymomonas mobilis, Fermentação contínua transitória, fermentação contínua.
\end{abstract}

\begin{abstract}
Ethanol production by Zymomonas mobilis CP4 under continuous transient operation has been investigated. The bacteria was grown under alternating glucose amplitudes of $2 \%$ and $5 \%(w / p)$ and cycle time values of 2, 4 and 6 hours. The ethanol production was compared to data obtained in simple chemostat operation grown $3.5 \%(\mathrm{w} / \mathrm{v})$ glucose medium. The value of dilution rate was fixed as $0.2 \mathrm{~h}^{-1}$ for both techniques. When cycle time value of 2 hours was used, values of biomass and ethanol kept constant. The appliance of cycle time of 4 hours produced smooth responses from the organisms. The values of biomass oscillated from 0.7 to $0.93 \mathrm{~g} / \mathrm{l}$. When cycle time of 6 hours was used the oscillations on biomass and ethanol were pronounced. The minimum and maximum values of biomass were respectively 0.61 and $1 \mathrm{~g} / \mathrm{l}$. As far as conversion efficiency to ethanol is concerned the values of 84,85 and $89 \%$ (corresponding to cycle time of 2, 4 and 6 hours) were found whereas conversion efficiency was low as $50 \%$ when simple chemostat was used.

Key words: continuous transient operation, continuous culture, Zymomonas mobilis
\end{abstract}

\footnotetext{
${ }^{1}$ Docente do Departamento de Bioquímica Universidade Estadual de Londrina - e-mail: buzato@uel.br

${ }^{2}$ Docente do Departamento de Bioquímica Universidade Estadual de Londrina
} 


\section{Introduction}

Microbial production in pratical applications strongly depends on the extra-cellular parameters of the system which are of the physical and chemical nature. Whereas the technical parameters are represented by the nutrients and other components, the physical ones depend on the features of the equipment such as cultivation method and type of equipment such as cultivation method and type of equipment selected.

Usually in based-Zymomonas mobilis ethanol production steady-state system is used (SABITA, 2002; MOHAGHEGHI et al., 2002; LAWFORD; ROSSEAU, 2002). However experimental and theoretical studies have demonstrated that cycling of fermenter conditions can increase average productivities and yelds (PICKETT, 1991; SAYLES; OLLIS, 1989).

The purpose of this study was to use define transient conditions of growth of Zymomonas mobilis as an alternative production procedure to batch or steady state continuous culture. Such technique of transient reactor operation has been reported by Pickett (1991), Constantinides and Mehta (1991); Cho et al. (2002) e Moller et al. (2002).

\section{Material and Methods}

Zymomonas mobilis CP4 was used throughout this study. This strains was originally isolated from fermented sugar cane juice from North East Brazil by Lima et al. (1970). The organisms were maintained by periodic transfer (every 4 weeks) into a new broth and incubated at $30{ }^{\circ} \mathrm{C}$ for 72 hours and subsequent storage at $4{ }^{\circ} \mathrm{C}$.

All continuous cultivation were carried out in a $0.5 \mathrm{~L}$ fermenter with $0.3 \mathrm{~L}$ working volume. The temperature was maintained at $35^{\circ} \mathrm{C}$ and a magnetic stirrer was used to provide mild agitation. The continuous addition of fresh medium was provided by means of an adjustable peristaltic pump and reactor contents left the vessel by an overflow pipe inserted through a side arm in the fermenter. Continuous culture experiments were preceded by a batch and when the culture achieved the exponential phase, the medium flow was started. The steady state was achieved after 2 days of cultivation.

The continuous transient condition (sometimes simply referred as square wave) took the form of subjecting a steady state chemostat culture with Zymomonas mobilis at a fixed value of dilution rate of $0.2 \mathrm{~h}^{-1}$ to continuous and repetitive variations in the input of glucose nutrient concentration. The square waves in input nutrient concentration were achieved by connecting the chemostat to two nutrient reservoirs, each containing complete, defined medium, but with glucose concentration of 2 and $5 \%(\mathrm{w} / \mathrm{v})$. At preset time intervals, a time system switched the nutrient feed between the two reservoirs.

The experimental culture medium contained (w/ p): $0.5 \%$ yeast extract, $0.1 \% \mathrm{KH}_{2} \mathrm{PO}_{4}, 0.1 \%$ $\left.\left(\mathrm{NH}_{4}\right)_{2} \mathrm{~S}\right)_{4}, 0.05 \% \mathrm{MgSO}_{4}$ and $3.5 \%$ glucose for simple chemostat and 2 and $5 \%$ glucose for continuous transient reactor operation.

The determination of biomass was made by measuring the absorption at $610 \mathrm{~nm}$ and the corresponding weight was obtained from a standard plot. Glucose was enzymatically determined using a kit based on the glucose oxidase-peroxidase system from Sigma. A gas-liquid chromatographic procedure was used to measure ethanol concentrations.

\section{Results and Discussion}

The culture of Zymomonas mobilis was grown under continuous transient operation which alternating glucose concentrations of 2 and $5 \%$, and cycle times of 2; 4 and 6 hours were used. The results obtained are shown in figures $1 ; 2$ and 3.

A general observation from de figures $1 ; 2$ and 3 is that as the cycle was shorter, the magnitude of the observed oscillations in biomass and ethanol decreased, until it became difficult to detect any change. 
Another general comment is that glucose in the reactor had its value increased over the second half of the cycle time as the system was being fed with higher glucose concentration medium while its value decreased when the lower glucose concentration medium was used. This was valid for any cycle time carried out.

When the culture was under cycle time of 2 hours, the values of biomass and ethanol were kept constant. The culture behaviour tended more toward a steady state condition. In other words, the culture showed features of being under relaxed steady state operation according to Bailey (1987). Under cycle time of 2 hours, the cells were apparently unable to respond to rapid changes in the growth environment, the changes occurring too rapidly for their metabolism to adjust accordingly inbetween. Alternatively, the cells could be responding to the imposed conditions but their response was too small to be detected experimentally. The value of biomass for cycle time of 2 hours was $0.78 \mathrm{~g} / \mathrm{L}$.

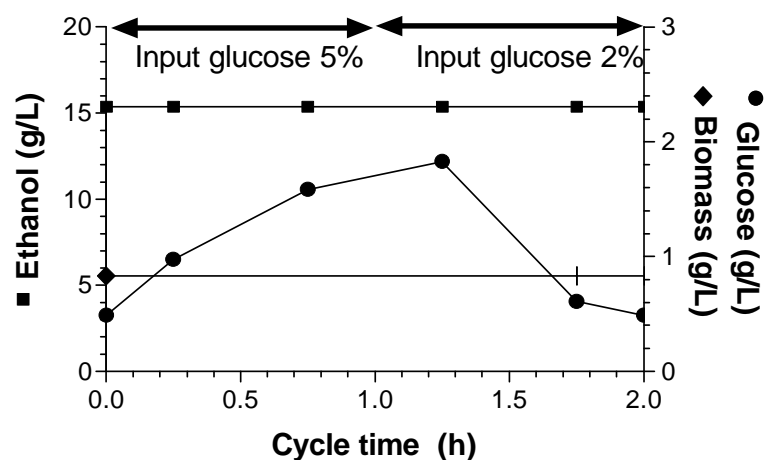

Figura 1 - Kinetics parameters for Z. mobilis growing in chemostat culture and subjected of fed glucose of 2 and $5 \%(\mathrm{w} / \mathrm{v})$ and cycle time of 2 hours. $\mathrm{D}=0.2 \mathrm{~h}^{-1}$

The appliance of cycle time of 4 hours produced smooth responses from the bacteria. Smooth oscillations on values of biomass and ethanol could be seen. The values of biomass oscillated from 0.7 to $0.93 \mathrm{~g} / \mathrm{L}$.

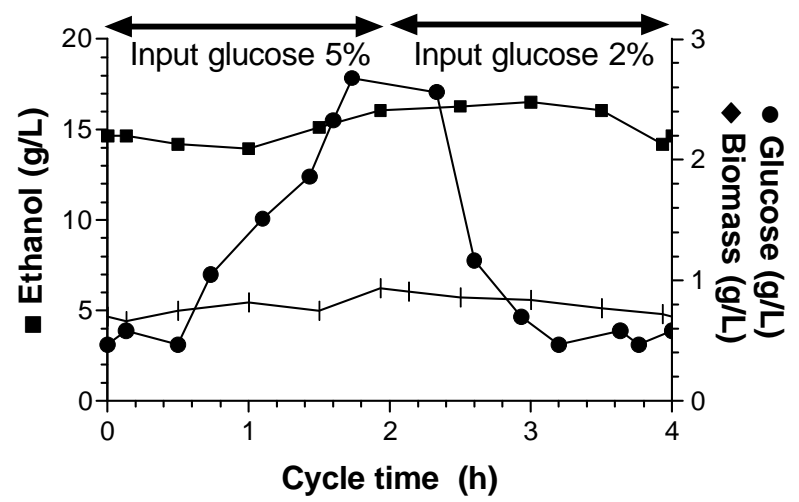

Figura 2 - Kinetics parameters for Z. mobilis growing in chemostat culture and subjected of fed glucose of 2 and $5 \%(\mathrm{w} / \mathrm{v})$ and cycle time of 4 hours. $\mathrm{D}=0.2 \mathrm{~h}^{-1}$

When cycle time of 6 hours was used, the behaviour of the culture was clearer when compared with cycle time of 4 hours as the oscillations on values of biomass and ethanol were more pronounced. The system was able to respond and changed dynamically according to the input of different concentrations of glucose.

The oscillatory response of the culture, with minimum value of biomass occurred just after the change to higher input nutrient concentration. At that point the culture produced a lag-phase like stage followed by a sigmoidally increase with time reaching its highest value of $1 \mathrm{~g} / \mathrm{L}$.

Over the second half of the cycle time, after the change to low input nutrient concentrations, the value of biomass dropped.

The response to shift-down in glucose concentration was always faster than the response to shipt-up. 


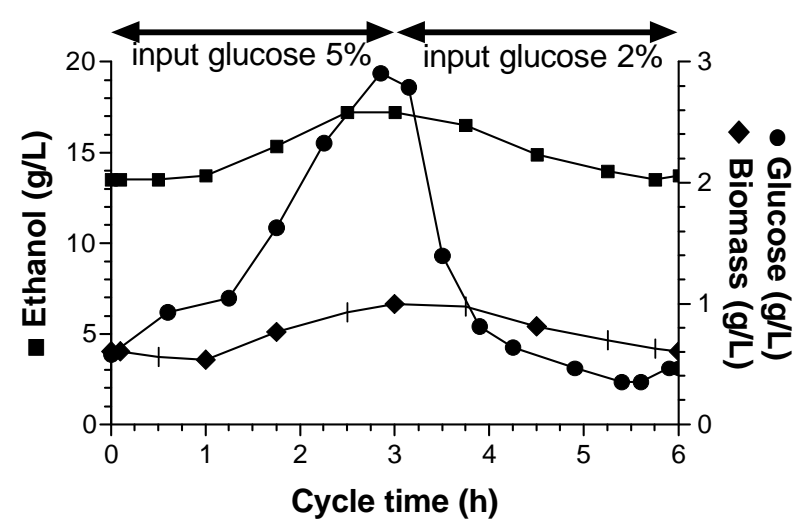

Figura 3 - Kinetics parameters for Z. mobilis growing in chemostat culture and subjected of fed glucose of 2 and $5 \%(\mathrm{w} / \mathrm{v})$ and cycle time of 6 hours. $\mathrm{D}=0.2 \mathrm{~h}^{-1}$

Borzani, Gregory e Vairo (1976) using an essentially undefined substrate of sugar cane molasses, examined the response of Saccharomyces cerevisiae to simple and complex cyclic variations in substrate concentrations. When square wave perturbation was used, the biomass varied sinusoidally in a manner qualitatively similar to fluctuations that observed in the present work.

As far as conversion efficiency to ethanol is concerned, the similar values of $84 ; 85$ and $89 \%$ of conversion efficiency values (corresponding to cycle time of 2; 4 and 6 hours) were found. The ethanol production was compared to data obtained in simple chemostat operation with $3.5 \%$ glucose medium at fixed dilution rate of $0.2 \mathrm{~h}^{-1}$ (results not shown). Steady state condition was achieved but only $50 \%$ of conversion efficiency to ethanol was reached.

\section{References}

BAILEY, J.E. Periodic phenomena. In: LAPIDUS, L.; AMUNDSON, N. R. (Eds). Chemical Reactor operation, a review. New York: Englewood Cliffs, 1987. p.758-813.

BORZANI, W; GREGORY, R. E. ; VAIRO, M. L. R. Response of a continuous anaerobic culture to periodic variation of the feeding mash concentration. Biotechnology and Bioengineering, New York, v.18, p.623-632, 1976.

CONSTANTINIDES, A.; MEHTA, N. Periodic operation of immobilized live cell bioreactor for the production of candicidin. Biotechnology and Bioengineering, New York, v.37, p.1010-1020, 1991.

CHO, H.W.; CHENG, G.S.; TSAO, T.G. Enhancement of oxygen transfer by pressure pulsation in aqueous glycerol fermentation. Applied Biochemistry And Biotechnology, Clifton, v.2, p.909-920, 2002.

LIMA, O. G. et al. Estudo de microrganismos antagonistas presentes nas bebidas fermentadas usadas pelo povo do Recife. Revista do Instituto de Antibioticos, Recife, v.10, p.3-15, 1970.

LAWFORD, H.G. ; ROSSEAU, J.D. Performing testing of Zymomonas mobilis metabolic engineered for cofermentation of glucose, xylose, and arabinose. Applied Biochemistry and Microbiology, New York, v.98, p.429-448, 2002.

MOHAGHEGHI, A. et al. Cofermentation of glucose, xilulose, and arabinose by genomic DNA-integrated xilose/arabinose fermenting strain of Zymomonas mobilis. Applied Biochemistry and Biotechnology, New York, v.98, p.885-898, 2002.

MOLLER, K. et al. Steady-state and transient-state analyses of aerobic fermentation in Saccharomyces kluyveri. FEMS Yeast Research, Amsterdam, v.2, n.2, p.233-244, 2002

PICKETT, A.M. Growth in a changing environment. BAZIN, M.J. (Ed.). Microbial population Dynamics. Boca Raton: CRC Press, 1991. p.91-124.

SABITA, D. Semi-continuous production of ethanol from agricultural wastes by immobilized coculture in a two stage bioreactor. Journal Environmental Biology, v.23, p.399-406, 2002.

SAYLES, G.D.; OLLIS, D.F. Periodic operation of immobilized cell system. Biotechnology \&

Bioengineering, New York, v.34:160-170,1989. 